\title{
Dialog i troska, czyli duszpasterz na współczesnych areopagach
}

Ks. Prof. Dr hab. Alfred MAReK Wierzbicki

Katolicki Uniwersytet Lubelski Jana Pawła II

\section{Przezwyciężyć cywilizację lęku}

Arcybiskup Józef Życiński znany był ze swej mobilności. Bywało, że godziny w samolocie podczas długich lotów międzykontynentalnych wykorzystywał na przygotowywanie wykładów. Rzadko kiedy uprawiał turystykę, zamiast zwiedzać ciekawe zakątki świata, w których przebywał, wolał w tym czasie spotykać się z ludźmi, aby z nimi porozmawiać. Ciągnęło go w odległe strony, gdyż czuł się biskupem epoki globalizacji. Zaczęła się za jego życia i na pewno nie odsłoniła jeszcze swego pełnego oblicza, ale on widział w niej przede wszystkim ogromną szansę dla nowej ewangelizacji.

Obecność abp. Życińskiego na licznych współczesnych areopagach wynikała z jego zdolności do odczytywania znaków czasu, towarzyszył jej apostolski zapał w stylu św. Pawła docierającego do różnorodnych środowisk Azji i Europy. Według Życińskiego Apostoł Narodów przełamywał 
bariery ówczesnego świata i niósł światło Ewangelii, będąc wolnym od kulturowych lęków. Zastanawiał się, czy św. Paweł napisałby Hymn o miłości, gdyby przeraził się rozpustą Koryntu. Podziwiał go za to, że nie zniechęcił się do Ateńczyków pogrążonych w jałowych dysputach i z entuzjazmem - pomimo sceptycyzmu swych rozmówców głosił bliskość nieznanego Boga. Świadomość dramatów świata i olśnienie blaskiem Ewangelii nie wykluczają się.

Metropolita lubelski we właściwym sobie zakresie i za pomocą dostępnych środków realizował duszpasterski program Jana Pawła II, zarysowany w homilii wygłoszonej w dniu inauguracji pontyfikatu w 1978 roku. Zwracając się do współczesnego świata, wielorako podzielonego, naznaczonego konfliktami i nieufnością, papież z Polski ukazywał Chrystusa jako źródło humanizmu i dlatego wołał:

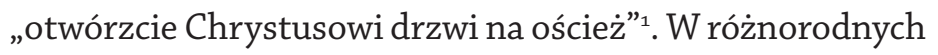
przestrzeniach współczesnego świata Jan Paweł II wskazuje na dziedziny polityki, ekonomii i kultury jako na miejsca otwarte dla Chrystusa. Zgodnie z nauczaniem Soboru Watykańskiego II, cechują się one względną autonomią związaną z ich własną celowością i jednocześnie mają głęboki sens humanistyczny ze względu na realizację człowieczeństwa za sprawą ludzkiej praxis. Chrześcijański humanizm jawi się jako twórcza - wyzwalająca z lęków - propozycja dla współczesnego świata, ponieważ Chrystus przynosi

1 Jan Paweł II, Nauczanie papieskie, red. ks. E. Weron, ks. A. Jaroch, t. 1, Poznań-Warszawa 1987, s. 15. 
poznanie prawdy o człowieku. Papieskie przesłanie z początku pontyfikatu brzmiało: „Nie lękajcie się! Chrystus wie, co jest w człowieku"2.

Wraz z Vaticanum Secundum Kościół zainicjował przełamywanie podwójnego lęku: lęku Kościoła przed światem i lęku świata przed Kościołem. Odpowiadając na wezwanie Jana Pawła II, abp Życiński nadał swej biskupiej posłudze wyraźny rys humanistyczny, połączony ze stylem dialogu będącego formą chrześcijańskiej obecności we współczesnym pluralistycznym świecie. Postawa dialogu rodzi się z głębszego zrozumienia istoty chrześcijaństwa jako religii wolności, proklamującej godność człowieka. Odpowiada ona również oczekiwaniom współczesnego świata, dumnego ze swych osiągnięć, dzięki którym prawda o wielkości i autonomii człowieka wyraziła się w przemianach cywilizacyjnych, jakie zaszły w świecie zachodnim w czasach nowożytnych. A jednocześnie nowożytność stała się areną ostrego starcia chrześcijaństwa, zwłaszcza w jego wersji katolickiej, z oświeceniową wizją emancypacji kultury ze sfery oddziaływania religii. Postawę dialogu należy odczytywać jako alternatywę dla postaw konfrontacyjnych, rządzących się logiką pokonania przeciwnika, celem dialogu nie jest bowiem pokonanie kogokolwiek, lecz zjednanie go sobie, a w pewnych sytuacjach również przekonanie go do swoich racji. Dialog zakłada zaufanie do drugiego i szacunek dla jego tożsamości. Odrzucenie lęku stanowi

\footnotetext{
2 Tamże.
} 
najpierw warunek wejścia na drogę dialogu, a potem okazuje się również jego dojrzałym owocem.

U podstaw dialogowego stylu duszpasterskiej działalności abp. Życińskiego znajdują się jego przemyślenia filozoficzne dotyczące kondycji współczesnej kultury. Diagnozuje on zarówno stan jej kryzysu, jak i kreśli wizję „wspólnoty ducha”, osiąganej na drodze spotkania ludzi poszukujących głębokiego sensu, dobra i piękna. Opublikowaną w 1990 roku, na początku jego biskupstwa książkę Trzy kultury ${ }^{3}$ trzeba odczytywać jako punkt dojścia wcześniejszej refleksji nad myślą Alfreda N. Whiteheada, poszukującego sposobu unifikacji duchowego doświadczenia człowieka, jednocześnie zawiera ona klucz do rozumienia chrześcijańskiej postawy Życińskiego wobec pluralizmu kultur w obrębie współczesnej cywilizacji zachodniej.

Intelektualno-estetyczna wizja religii rozwijana przez brytyjskiego myśliciela w pierwszej połowie XX wieku inspirowała Józefa Życińskiego do poszukiwania syntezy nauk przyrodniczych, humanistyki i myślenia religijnego. Życiński zawdzięczał Whiteheadowi ideę wielowymiarowej rozmaitości sensu. Należy poszukiwać wspólnego sensu, ale nie wolno mieszać płaszczyzn dyskursu. „Rywalizacja w tłumaczeniu świata występowała

3 J. Życiński, Trzy kultury, Poznań 1990.

4 Zob. A.M. Wierzbicki, Szeroko otwierał drzwi Kościoła, Lublin 2016, s. 147 i nast. 
wówczas - wyjaśnia Życiński - kiedy na tej samej płaszczyźnie umieszczano teorie przyrodnicze i ich «uzupełnienia» teologiczne, impresje artystyczne i komentarze metafizyków. Pozorne przeciwstawienia znikają jednak, jeśli uznamy, iż przy pomocy zróżnicowanych środków poznawczych możemy odkrywać rzeczywistość sensu posiadającą obiektywną wartość dla naszego pojmowania świata"s. Życiński - za Whiteheadem - głosi tezę o przydatności różnych języków w docieraniu do sensu, co więcej, wielość języków nie stanowi dla niego ułomności, lecz odzwierciedla bogactwo ludzkiego umysłu.

Podobną inspirację w dążeniu do syntezy kultur, unifikujących badania przyrodnicze, dociekania humanistyczne, twórczość artystyczną i religię, Życiński czerpał z intelektualnej postawy szwajcarskiego teologa Hansa Ursa von Balthasara, głoszącego pogląd na temat symfoniczności prawdy. Według katolickiego teologa różnorodność głosów, wielość melodii staje się harmonijna w intelektualnej przestrzeni chrześcijańskiego Objawienia. „W swoim Objawieniu Bóg wystawia symfonię. Trudno powiedzieć, co jest w niej bogatsze: jednolity pomysł Jego kompozycji czy też polifoniczna orkiestra stworzenia, którą sobie w tym celu przygotował. Zanim Słowo Boże stało się człowiekiem, orkiestra świata rzępoliła sobie a muzom: światopoglądy, religie, wiele projektów państw, każdy gra coś, nie bacząc na innych. Jakoś przeczuwa się, że to kakofoniczne zamieszanie

5 J. Życiński, Trzy kultury, dz. cyt., s. 124. 
było jedynie «wprawianiem się w grze»: dźwięk A brzmi, przenikając wszystko niby obietnica" ${ }^{\text {. }}$

Dążąc do syntezy języków nauki, religii i sztuki, Życiński uściślał swe stanowisko, aby uniknąć błędów metodologicznych i nie popadać w pułapkę myślenia eklektycznego. Uznawał autonomię dyskursów, podkreślał znaczenie naturalizmu metodologicznego, nakazującego interpretację danych empirycznych w zgodności z ich treścią i jednocześnie przeciwstawiał się naturalizmowi metafizycznemu, redukującemu klasę realnie istniejących bytów wyłącznie do tych, które są stwierdzalne metodami empirycznymi. Komentując encyklikę Fides et ratio, wskazywał na zasadę komplementarności języków. „Powtarzany wielokrotnie w nauczaniu Jana Pawła II postulat dialogu teologii i nauk przyrodniczych niesie szansę unifikacji filozoficznej, w której w miejsce wcześniejszych przeciwstawień pojawi się nowa synteza. Spełnienie tego postulatu, zamiast znanego napięcia między teizmem a naturalizmem wprowadzi harmonię komplementarnych ujęć. Niosą one szansę przeciwdziałania wycinkowym schematom interpretacyjnym, w których nierzadko ideologia dominowała nad racjonalnymi uzasadnieniami"”. W latach, w których dominowała jeszcze w wielu ośrodkach akademickich i pozaakademickich intelektualna kultura neopozytywistyczna,

6 H.U. von Balthasar, Prawda jest symfoniczna, tłum. I. Bokwa, Poznań 1998, s. 6.

7 J. Życiński, Transcendencja i naturalizm, Kraków 2014, s. 16. 
Życiński w swych pracach podważał wąskie rozumienie racjonalności, na gruncie którego negowano poznawczą wartość religii, metafizyki i sztuki, natomiast w następnych dekadach, w których postmodernizm zaczął ogarniać umysły i relatywizowano wszelkie prawdy, Życiński występował jako obrońca myślenia racjonalnego, dającego podstawy uniwersalizmowi aksjologicznemu. W jednym i drugim przypadku, gdy angażował się w debaty, przybierające nierzadko formę ostrych polemik, nie poprzestawał na krytyce neopozytywizmu czy postmodernizmu, lecz w sposób konsekwentny rozwijał perspektywę syntezy współczesnej nauki i teizmu.

\section{Kongresy kultury: ku syntezie języków i doświadczeń}

Teoretyczna refleksja nad syntezą trzech kultur, prowadzona na przełomie lat osiemdziesiątych i dziewięćdziesiątych XX wieku w ramach autorskiej filozofii kultury, na początku XXI wieku została rozwinięta w wysiłku zespołowym za sprawą kongresów kultury chrześcijańskiej, odbywających się w Katolickim Uniwersytecie Lubelskim z inicjatywy abp. Józefa Życińskiego. Impulsem do zorganizowania I Kongresu w roku 2000 był Wielki Jubileusz Chrześcijaństwa. W rozmowie, jaką przeprowadziłem z twórcą tego Kongresu zaraz po jego zakończeniu, podkreślał on troskę o uniwersalny charakter kultury chrześcijańskiej. Cieszył się z odzewu, z jakim spotkał 
się lubelski kongres, w którym uczestniczyli chrześcijanie, żydzi, ateiści, duchowni, myśliciele i twórcy. Prócz pluralizmu postaw i inspiracji podczas obrad kongresu przejawiała się solidarność ludzi z różnorodnych środowisk pochylających się nad ogólnoludzkimi wartościami. W zamyśle abp. Życińskiego zadaniem kongresu było „poszukiwanie tych środków i inspiracji intelektualnych, które pozwoliłyby na odnalezienie uniwersalnych wartości w «globalnym mieście». Trudno pogodzić się z sugestiami, że proces globalizacji zachodzący na poziomie gospodarczym i przepływu informacji winien iść $\mathrm{w}$ parze $\mathrm{z}$ postawą subiektywizmu oraz relatywizmu, która nie pozwala na wypracowanie zbioru fundamentalnych, ogólnoludzkich wartości. Nie chcieliśmy podczas kongresu popadać w patos, znany choćby z wrocławskiego Kongresu Obrońców Pokoju z roku 1948. Naszym celem było natomiast skierowanie uwagi na ten elementarny zbiór wartości humanistycznych, którego usunięcie z kultury mogłoby doprowadzić do katastrofy aksjologicznej”"

Dyskusje na areopagu nie zmieniają od razu rzeczywistości. Myślenie i twórczość cechują się wysoką dawką bezinteresowności. Wiedział o tym Auden, gdy pisał, że poezja niczego nie zmienia („,For poetry makes nothing happen"), ale to dzięki niej rzeczy trwają i zachowują swą

\footnotetext{
8 A.M. Wierzbicki, Szeroko otwierał drzwi Kościoła, dz. cyt., s. 18-19.

9 W.H. Auden, In Memory of W. B. Yeats, w: tenże, Selected Poems, London-Boston 1987, s. 82.
} 
istotę. Kongresy kultury organizowane przez abp. Życińskiego wyrastały z troski o poważną rozmowę dotyczącą kondycji ludzkiej na progu nowego tysiąclecia. Fragmentaryzacja wiedzy, zanik wielkich pytań wypieranych przez konsumpcję i rozrywkę, agresywny relatywizm, fanatyczny fundamentalizm nie wyczerpują opisu współczesnej kultury. Cechuje ją bowiem napięcie, dzięki któremu trwa poszukiwanie światła i nadziei. Ponieważ abp. Życińskie$\mathrm{mu}$ bardzo zależało na samej atmosferze kongresowych spotkań, wykładom i dyskusjom panelowym towarzyszyły wydarzenia artystyczne, takie jak: spektakle teatralne, filmy, koncerty, wystawy oraz wspólna modlitwa i oczywiście będące żywiołem wszelkich oficjalnych spotkań rozmowy w kręgu przyjaciół.

Arcybiskup Życiński zorganizował trzy kongresy: w 2000, 2004 i 2008 roku, a czwarty planował na rok 2012. Nie sposób w tym krótkim szkicu omówić szczegółowo problematyki, wokół której debatowano, wypada ograniczyć się do stwierdzenia, że towarzyszyła ona ówczesnym debatom publicznym. Pierwszy z kongresów zatytułowany „Chrześcijańskie korzenie przyszłości” wskazywał na tożsamość i rozwój kultury chrześcijańskiej. Drugi odbywał się w momencie, kiedy dyskutowano na temat integracji Polski z Unią Europejską, dlatego próbowano zrozumieć aksjologię Europy jako wspólnoty ducha oraz rolę chrześcijan w procesach integracyjnych. Trzeci kongres odbywał się w roku 2008, kiedy świat zachodni przeżywał nowy kryzys ekonomiczny, podejmowano wtedy pogłębioną refleksję 
aksjologiczną wokół pytania: „Godność czy sukces?”. Arcybiskup Życiński zawsze akcentował, że kongres kultury powinien się różnić od kongresów dyscyplinarnych, gromadzących specjalistów, np. biologów, ekonomistów czy teologów. Ten kongres miał być raczej miejscem spotkania ludzi Kościoła i ludzi kultury, znakiem wspólnoty ludzi poszukujących sensu.

Od początku lat dziewięćdziesiątych uczestniczył w pracach powołanej przez Jana Pawła II Papieskiej Rady Kultury, inspirowało go to do realizowania podobnego dialogu z kulturą współczesną w wymiarze Kościoła lokalnego, za który był odpowiedzialny. Można powiedzieć, że w pewnym sensie lubelskie kongresy kultury - gromadzące katolików i niekatolików, wierzących i agnostyków stały się jakąś antycypacją tej formy dialogu, jaką zaczęła upowszechniać Papieska Rada Kultury w czasie pontyfikatu Benedykta XVI, którą nazwano „Dziedzińcem Pogan” lub „Dziedzińcem Dialogu”.

\section{Wartości w eterze, na antenie i w drodze}

Trudno przecenić znaczenie mediów jako areopagu, na którym krzyżują się różnorodne nurty kultury współczesnej, jej drogi i bezdroża. Arcybiskup Życiński poruszał się $\mathrm{z}$ wielką swobodą $\mathrm{w}$ krajobrazie mediów katolickich i publicznych. Publikował w „Tygodniku Powszechnym”, „Gościu Niedzielnym”, w miesięcznikach „Znak”, „Więź”, „W Drodze”, w kwartalniku „Ethos” oraz 
w „Rzeczpospolitej”, , „Gazecie Wyborczej”, „Newsweeku”. Nie ograniczał się do jednego tytułu prasowego. Uczestniczył w programach kilku stacji telewizyjnych, przez kilkanaście miesięcy był autorem felietonu w I Programie Polskiego Radia, a przez 14 lat co tydzień nagrywał $\mathrm{Pa}$ sterski kwadrans dla katolickiego „Radia er”. Wśród księży w Lublinie krążył dowcip, że boją się otworzyć tabernakulum, aby nie wyskoczył z niego ich Arcybiskup. Była to bardziej pobożna wersja dowcipu o lodówce. W innym dowcipie znajduje się echo zwyczaju zwoływania konferencji prasowych przez Arcybiskupa. Ponoć św. Piotrowi przyszedł chytry pomysł do głowy, jak ściągnąć metropolitę lubelskiego z tronu Bożego, który przybysz z Lublina nieświadomie zajął podczas wycieczki do nieba. Powiedział mu, że zaraz będzie konferencja prasowa i trzeba na nią pójść do innej sali. W żartach tych odbija się fakt głębokiego wrośnięcia abp. Życińskiego w media i posługiwania się nimi jako instrumentami duszpasterskiej obecności w pluralistycznym świecie. Publicystyka abp. Życińskiego stanowi wyraźny dział wśród jego publikacji książkowych. Publikowane wcześniej w prasie artykuły zbierał potem w książkach, nadając w ten sposób rozważaniom i przemyśleniom, zrodzonym w kontekście aktualnych wydarzeń, na które reagował - zgodnie z logiką mediów - na bieżąco, charakter bardziej uporządkowanej refleksji na temat dylematów współczesności. Obok esejów, nasyconych erudycją, iskrzących się poczuciem humoru, opublikował kilka tomików rozważań osnutych 
na motywach Ewangelii, w których głębia osobistej medytacji łączy się ze świadomością lęków i dramatów ludzi współczesnych ${ }^{10}$.

Publicystyka abp. Życińskiego polegała na zmierzeniu się z wyzwaniami postmodernizmu. Oprócz inspirujących intelektualnie nurtów postmodernizmu, w których dokonywało się przewartościowanie wyolbrzymionych aspiracji moderny, dekonstrukcja iluzji wielkich narracji zrodzonych z ducha Oświecenia, postmodernizm rozlał się w meandrach kultury masowej, stając się postmodernizmem populistycznym. Z jednej strony abp Życiński prowadził filozoficzną dyskusję z postmodernizmem, uważnie wsłuchując się w głosy jego rzeczników, życzliwie traktując ich obawy wobec totalizującego stylu myślenia, dostrzegając nostalgię za utraconym Bogiem, z drugiej natomiast strony stawał się bezlitosnym demaskatorem intelektualnego i moralnego szalbierstwa propagatorów postmodernizmu populistycznego. Raziło go połączenie najnowszej techniki, wzmacniającej potencjał istot ludzkich, z prymitywizmem moralnym, z klimatem bezmyślnej lekkości, z naskórkowym przeżywaniem ludzkiego losu, z którego eliminuje się zarówno pęknięcie i jego dramatyczność, jak i nadzieję

10 Warto przypomnieć te publikacje abp. Józefa Życińskiego: $\mathrm{Na} \mathrm{Za-}$ chód od domu niewoli, Poznań 1997; Wartości w eterze, Lublin 1999; Kuszenie Pana Cogito, Lublin 200o; Pożegnanie z Nazaretem, Lublin 2000; Pan Cogito czy Mister Tarzan?, Lublin 2001; Od Manhattanu do Emaus, Lublin 2003; Odyseusz czy playboy? Kulturowa odyseja człowieka, Kraków 2005; Okruchy słowa, Lublin 2005; Okruchy nadziei, Lublin 2008. 
doczesną i eschatologiczną. Wobec groźby przemiany gatunku homo sapiens w człowieka bez właściwości przypisywał ludziom nauki, ambitnym twórcom i teologom wspólne zadanie budzenia fascynacji wartościami i wyrabiania zmysłu krytycznego. Był intelektualistą, który zrozumiał, że nie można zamknąć się w wieży kontemplacji w sytuacji tak drastycznego rozchodzenia się kultury wysokiej i kultury masowej. Traktował media jako sferę nowej ewangelizacji, do której przygotowaniem powinna być kultura, poddana próbie rozumu i serca. Nie zrażał się pluralizmem, miał dosyć chrześcijańskiego optymizmu, aby nie ogłaszać końca człowieczeństwa. Sądził, że „pokolenie «wrzuconych w pluralizm» staje dziś przed trudniejszym niż kiedykolwiek kulturowym wyzwaniem. Podjęcie nowych wyzwań wymaga zarówno krytycznej refleksji, jak i dystansu wobec mozaiki piętrzących się wrażeń. Nie sprzyja temu bynajmniej codzienna dawka reklam i szumu informacyjnego. Dlatego też współczesny Odyseusz staje wobec zadań trudniejszych niż jego klasyczny poprzednik"11.

Postaci hedonisty pogrążonego w przyjemnościach i amnezji autor eseju Odyseusz czy playboy? przeciwstawia postać Odyseusza wiernie pamiętającego o utraconej ojczyźnie. Wiadomo choćby z przemyśleń św. Augustyna czy Bergsona, że pamięć buduje naszą podmiotową tożsamość, a kard. Josef Ratzinger wiązał ją z najgłębszą

${ }_{11}$ J. Życiński, Odyseusz czy playboy? Kulturowa odyseja człowieka, dz. cyt., s. 21. 
strukturą sumienia. Podobnie w antropologii Życińskiego pamięć Odyseusza jawi się jako niezawodna busola w jego pełnych perypetii wędrówkach. Odyseusz jakoś przypomina człowieka postmodernistycznego, prowadzącego powierzchowną egzystencję turysty, obydwaj są w drodze, dokądś zmierzają. Odyseusz góruje jednak nad wykorzenionym nomadą swą wierną pamięcią, jego kultura to „kultura serca”, a nie „kultura chwili”. Wędrówka Odyseusza może się przeobrazić w wędrówkę Abrahama. „Przyjąć wędrowny styl Abrahama w kulturowym kontekście postmoderny to umieć ze spokojem zwinąć namiot bliskich nam pojęć i argumentów nie po to, aby porzucić go na pustynnym szlaku, lecz aby rozbić go w innym kontekście i w innej formie na terenie wyznaczonym przez Boga"12. Współczesny duszpasterz wiedział, że szlak Abrahama ma wiele form, dlatego z podobną wrażliwością towarzyszył młodzieży pielgrzymującej do Częstochowy, jak i spotykał się z młodzieżą przybywającą na Przystanek Woodstock. W jednych i drugich widział oblicze Abrahama, chociaż miało ono odmienne, niezbyt podobne do siebie, rysy.

\section{Dialog, który stawał się troską i współczuciem}

Arcybiskup Życiński występował na współczesnych areopagach jako myśliciel wyrażający troskę o racjonalną kulturę

12 Tamże, s. 59.

172 - Ks. prof. dr hab. Alfred Marek Wierzbicki 
myślenia zbiorowego, w ten sposób wypełniał swoje powołanie intelektualisty. Postawa intelektualisty $\mathrm{w}$ jego przypadku była głęboko zrośnięta z postawą duszpasterza, przejawiał troskę nie tylko o idee, ale potrafił wychodzić naprzeciw dramatom przeżywanym przez konkretne osoby. O niektórych z nich dowiadywał się z ich publikacji, na które reagował w swych publicznych wystąpieniach oraz w prywatnej korespondencji.

Wymiana korespondencji ze Zbigniewem Herbertem nastąpiła dopiero w ostatnich latach życia poety. W udzielonym mi wywiadzie Arcybiskup wspominał: „Moja korespondencja z nim została sprowokowana przez artykuł, w którym pisząc o współczesnych poszukiwaczach Boga, jako motta użyłem fragmentu z wiersza Herberta Homilia. Herbert przeczytał mój tekst i radość sprawił mu fakt, że jego poszukiwania i inspiracje okazują się bliskie odczuciom biskupa. Przysłał mi tomik Epilog burzy z dedykacją poprzedzającą jego refleksję o św. Tomaszu Apostole. Wydaje mi się, że wiersze tego autora wyrażają nie tylko jego osobiste odczucia. Wśród współczesnych twórców kultury bardzo często można spotkać ludzi, którzy nie potrafią poradzić sobie $z$ fundamentalnymi pytaniami o Boga, sens, cierpienie czy miłość. [...] Są sytuacje, w których zawodzi klasyczna logika Arystotelesa, ale skuteczną może okazać się logika ran. Osoby poranione przez życie i szamoczące się z bagażem swoich problemów w zetknięciu z chrześcijaństwem żywym, które pozwala dotykać najbardziej czułych punktów, odnajdują perspektywę rozwiązania swoich 
życiowych rozterek. Istnieje mało znana filozofom logika ran, poprzez którą człowiek znajduje ukojenie swych wątpliwości” ${ }^{13}$.

Empatia, z jaką abp Życiński odczytywał Herbertowski wiersz, w którym poeta burzy się na paternalistyczny styl kaznodziei, stała się okazją do spotkania, w którym ludzie przestają się porozumiewać hasłami, a serce zaczyna mówić wprost do serca (Cor ad cor loquitur, jak powtarzał kard. John H. Newman).

\section{[...]}

bo dla księdza - proszę księdza - to jest wszystko takie proste

Pan Bóg stworzył muchę żeby ptaszek miał co jeść

Pan Bóg daje dzieci i na dzieci i na kościół

prosta ręka - prosta ryba - prosta sieć

może tak należy mówić ludziom cichym ufającym

obiecywać - deszcze łaski - światło cud lecz są także tacy którzy wątpią niepokorni bądźmy szczerzy to jest także boży lud

proszę księdza - ja naprawdę Go szukałem i błądziłem w noc burzliwą pośród skał

${ }_{13}$ A.M. Wierzbicki, Szeroko otwierał drzwi Kościoła, dz. cyt., s. 32-33. 
piłem piasek jadłem kamień i samotność

tylko Krzyż płonący w górze trwał

$[\ldots]$

\section{$\left(\right.$ Homilia $\left.^{14}\right)$}

Czytelnik w sutannie i piusce potraktował ten wiersz jako skargę człowieka, który poczuł się odepchnięty przez jakiegoś duszpasterza. Wysłuchał jej i odpowiedział gestem przyjaźni i solidarności z niepokorną - poszukującą - częścią „bożego ludu”, która bynajmniej nie jest zjawiskiem marginalnym. Warto pamiętać o tym punkcie współczesnej poezji polskiej, w którym skarga poety spotyka się z otwartością biskupa, wskutek tego, że nauczaniu duchownego towarzyszy zdolność do wsłuchiwania się w głosy bliźnich.

Arcybiskup wielokrotnie angażował się w obronę dobrego imienia ludzi, których niesłusznie i niegodziwie atakowano w mediach. Przypomnijmy jego postawę wobec insynuacji pod adresem Jana Nowaka-Jeziorańskiego. Na łamach „Naszego Dziennika” i falach Radia Maryja zaczęto rozpowszechniać informacje o rzekomej kolaboracji legendarnego kuriera z Warszawy z hitlerowskim okupantem w latach II wojny światowej. We wspomnieniu napisanym po śmierci Nowaka abp Życiński opublikował

${ }_{14}$ Z. Herbert, Homilia, w: tenże, Rovigo, Wrocław 1992, s. 26-27. 
list od swego przyjaciela zawierający zwierzenia człowieka przeżywającego krzywdę. Bardzo bolało i gorszyło wierzącego i głęboko oddanego Kościołowi działacza, dziennikarza i pisarza, że jej sprawcą był duchowny. „Z ogólnego punktu widzenia moja osoba nie ma tu większego znaczenia. Z głęboką troską myślę o tym, że nieustanna ekspansja i propaganda Radia Maryja może przynieść swoje złowrogie owoce dopiero w dłuższej perspektywie czasu, kiedy mnie już nie będzie. [...] Przez dłuższy czas wydawało mi się, że religijna część audycji, która z kościelnego punktu widzenia wydaje się być bez zarzutu, zaspokaja autentyczną potrzebę radia modlitewnego. Nabieram obecnie przekonania, że służy ona celowo jako przynęta albo raczej kapsułka, którą odbiorca przełyka, nie zdając sobie sprawy, że zawiera truciznę"15. Twórcę Radia Wolna Europa niepokoiły przede wszystkim społeczne skutki katolickiej publicystyki, uwikłanej w jakąś mętną polityczną grę.

Niepokoje te podzielał abp Życiński, czemu dawał wyraz w swych krytycznych opiniach o mediach ojca Tadeusza Rydzyka, w trosce o spójność ich przekazu z Ewangelią. Narażając się sporej grupie swych wiernych, traktujących toruńską rozgłośnię jak wyrocznię, odważnie bronił dobrego imienia Jana Nowaka-Jeziorańskiego. Posługiwania się kłamstwem nie da się pogodzić z ideą „,katolickiego głosu”,

15 J. Życiński, Świadek dwóch miłości, w: Jan Nowak-Jeziorański (19132005), red. A.M. Wierzbicki, Lublin 2006, s. 41-42. 
narusza ono podstawowe zasady moralne. Nie ukrywał rozczarowania faktem, że w toruńskich mediach nigdy nie doszło do przeproszenia niewinnie oskarżonego człowieka, gdy „sprawa Nowaka” została wyjaśniona przez Pawła Machcewicza po odnalezieniu $\mathrm{w}$ archiwach Instytutu Pamięci Narodowej dokumentu, świadczącego o prowokacji peerelowskiej Służby Bezpieczeństwa. Źródłem fałszywej informacji, zniesławiającej narodowego bohatera, okazał się Witold Trościanko, emigracyjny działacz Stronnictwa Narodowego, rywalizujący z Nowakiem redaktor Radia Wolna Europa. O kulisach tej prowokacji i jej fatalnych konsekwencjach pisze Paweł Machcewicz w artykule opublikowanym w książce poświęconej biografii Jana Nowaka-Jeziorańskiego ${ }^{16}$.

Zaskoczenie, a nawet dystansowanie się, budziło wezwanie abp. Życińskiego, aby nazbyt pochopnie nie potępiać Krzysztofa Piesiewicza, kiedy ujawniono okoliczności szantażu, w jaki został wplątany znany polityk, wcześniej obrońca więźniów politycznych i genialny współscenarzysta filmów Krzysztofa Kieślowskiego. Na pewno Arcybiskupowi chodziło o obronę człowieka cieszącego się społecznym autorytetem, niestety po 1989 roku nazbyt często atakowano ludzi, aby pomniejszać ich zasługi. Jednak w przypadku tarapatów Piesiewicza chodziło nie tylko o obronę znakomitego twórcy przed demonami pogardy.

16 P. Machcewicz, Stużba Bezpieczeństwa przeciwko Janowi Jeziorańskiemu, w: Jan Nowak-Jeziorański (1913-2005), dz. cyt., s. 65-91. 
W słowach abp. Życińskiego, wypowiedzianych na konferencji prasowej, zawierało się współczucie dla kogoś, kto sam poprzez swoją lekkomyślność zaszkodził sobie. Arcybiskup mógł wygłosić moralizatorską tyradę o zgubnych skutkach, wręcz o moralnej degradacji, do jakiej prowadzi używanie narkotyków i uzależnianie się od podejrzanych osób, ale przecież takimi słowami nie pomaga się człowiekowi zranionemu. Miłosierdzie to wcale nie pobłażliwość dla zła, jego istotą jest poszukiwanie sposobów pokonywania zła siłą dobra.

Wystarczyło, że do abp. Życińskiego dotarła nawet w pośredni sposób informacja o czyichś zmaganiach duchowych, a już śpieszył ze swą dyskretną troską. W rozmowie z Aleksandrą Klich wspominał, jak głęboko współczuł nieznanej osobiście artystce. „A jak strasznie cierpiała i wątpiła pani Anda Rottenberg. Mam nadzieję, że nie będzie miała do mnie pretensji, że ją wspominam. Ale jej książka o walce o życie uzależnionego od narkotyków syna bardzo mnie poruszyła. Nie mogłem się powstrzymać i napisałem do niej list $\mathrm{z}$ wyrazami solidarności” ${ }^{17}$. Tego typu opowieści przekonują, że poruszając się w otwartych i skomplikowanych przestrzeniach współczesnej kultury, debatując na areopagach, tocząc spory o idee, abp Życiński nigdy nie odrywał swego spojrzenia od konkretnego człowieka i jego dramatów. Tak wysoki poziom ludzkiej empatii czynił go

${ }_{17}$ J. Życiński, A. Klich, Świat musi mieć sens. Przerwana rozmowa arcybiskupa Józefa Życińskiego i Aleksandry Klich, Warszawa 2012, s. 24. 
autentycznie wiarygodnym uczestnikiem debat na współczesnych areopagach.

Media - Kultura - Dialog. W piąta rocznicę śmierci arcybiskupa Józefa Życińskiego, red. ks. R. Nęcek, ks. W. Misztal, Kraków 2017, s. 159-179.

DOI: http://dx.doi.org/10.15633/9788374385848.15 